\title{
TELEPON SELULER DALAM PERSPEKTIF ISLAM
}

\section{Oleh A.Nur Aisyah Rusnali}

\begin{abstract}
Abstract The development of communication technology is now progressing day by day. Not surprisingly, if the use of communication technology seems to be a basic need for every human being on this earth. One form of communication technology development that is increasingly fast is cellular phones. Cellular telephone companies both from within and outside the country increasingly compete to produce cellular phones with good quality and lower prices. This is certainly more tempting for consumers. In addition, cell phones are now not only limited to calling and sending short messages, but the social media features are increasingly attractive and curious for every user. In Islam, technological development has actually been explained in the Qur'an surah Yunus / 101, then in QS. An-Naml / 40 which contains information, and there are many more verses in the Koran that explain the development of technology. When we use it wisely, Islam also views this handphone as very useful because it facilitates difficulties when interacting with the environment and surrounding communities. However, if this cellphone is used poorly, then Islam will view that handphone has many disadvantages and can plunge the user into immorality which of course is not desired by Islam itself.
\end{abstract}

Kata Kunci: telepon seluler, perspektif Islam.

\section{Pendahuluan}

Saat ini, kita hidup pada era informasi, sebuah era ketika media komunikasi telah menjadi pusat dari hampir semua yang kita lakukan. Alat untuk pengiriman transmisi dan menerima informasi selalu menempati tempat penting dalam aktivitas manusia. Dewasa ini teknologi komunikasi semakin berkembang dan terus maju. Telepon genggam atau yang lebih dikenal dengan sebutan HP (handphone) merupakan salah satu alat komunikasi yang sedang digemari oleh banyak orang. Hampir seluruh pelosok Indonesia sudah dapat menikmati manfaat dari telepon seluler. Sinyal telepon seluler sudah mampu menembus sampai ke daerah pelosok di Indonesia.

Saat ini, telepon seluler sudah menjadi kebutuhan pokok bagi umat manusia. Mulai dari yang tua sampai yang muda, semua seolah mengalami kecanduan terhadap teknologi telepon seluler ini. Di satu sisi, handphone memiliki dampak positif, diantaranya adalah dapat mempermudah komunikasi, menambah pengetahuan tentang perkembangan teknologi, dan memperluas atau mempererat silaturahmi. Dari dampak positif tersebut, telepon seluler juga memiliki dampak negatif, diantaranya adalah dapat menciptakan lingkungan pergaulan sosial yang tidak sehat, kurang 
bersosialisasi secara langsung dan juga dapat menyebebkan terjadinya tindak kejahatan. ${ }^{1}$

Pada dasarnya kita hidup di dunia ini tidak lain untuk beribadah kepada Allah SWT. Ada banyak cara untuk beribadah kepada Allah SWT seperti sholat, puasa dan menuntut ilmu. Menuntut ilmu hukumnya wajib. Seperti sabda Rasulullah SAW: "mencari ilmu adalah sebuah kewajiban atas setiap muslim laki-laki dan perempuan" (HR. Ibnu Abdil Barr). ${ }^{2}$

Telepon seluler merupakan hasil cipta manusia, yang seyogyanya digunakan untuk memudahkan urusan umat manusia. Seperti yang diterangkan dalam QS.Yunus/ 101:

منون يُ ؤ لاقوم عن وال نذر يـ ت لات خني ومارض والات ال سموا في ذا ماذظروا اقل

Artinya: Katakanlah: "Perhatikanlah apa yang ada di langit dan di bumi. Tidaklah bermanfaat tanda kekuasaan Allah dan rasul-rasul yang memberi peringatan bagi orang-orang yang tidak beriman." (QS Yunus : 101) ${ }^{3}$

Jadi sebenarnya, jauh sebelum penemuan teknologi ada, Al- Quran telah menjelaskan tentang keberadaannya di masa yang akan datang. Kecanggihan tekno;ogi yang ada saat ini, serta merta diciptakan manusia untuk mememnuhi segala kebutuhan. Jadi sebaiknya, teknologi tersebut juga dipergunakan sesuai maksud dan tujuan pembuatannya, bukan malah menyalah gunakan penggunaan tenologi tersebut.

\section{Pembahasan}

\section{Pengertian Telepon Seluler}

Telepon seluler atau yang dikenal dengan istilah Handphone adalah suatu alat komunikasi tanpa menggunakan kabel. Sejarah perkembangan Handphone bermula di awal abad 19. Pada tahun 1910, permulaan telepon seluler yang ditemukan oleh Lars Magnus Ericsson (Swedia), pendiri perusahaan Ericsson yang kini dikenal dengan perusahaan Sony Ericsson dan merupakan bidang bisnis telegraf.

Lalu pada tahun 1970, perkembangan telepon mobile didominasi oleh 3 perusahaan besar yaitu di Eropa dengan perusahaan Nokia dan Motorola, diawali dengan penggunaan mikroprosesor untuk teknologi komunikasi. Pada tahun 1971, jaringan handphone pertama dibuka di Finlandia bernama ARP. Baru-baru ini, tren komunikasi mulai beralih menjadi teknologi seluler yang menjanjikan. Semakin canggih teknologi handphone ini terlihat dari kecepatan transfer data, menyediakan layanan internet, memiliki fasilitas kamera, video, radio dan lain-lain. Kecanggihan tersebut sangat mempermudah manusia dalam hal berkomunikasi tanpa mengenal jarak dan waktu.

\footnotetext{
${ }^{1}$ Saydam, Gouzali. Teknologi Telekomunikasi ( Perkembangan dan Aplikasi) (Jakarta: Alfabeta, 2005).h. 8.

${ }^{2}$ Syuhudi Ismail, Pengantar Ilmu Hadis, h. 53.

${ }^{3}$ Departemen Agama RI, Al-Qur'an Dan Terjemahannya, h. 587.
} 
Al-Quran memuji sekelompok manusia yang dinamainya ulil albab. Ciri mereka antara lain disebutkan dalam surat Ali-'Imran (3) 190-191:

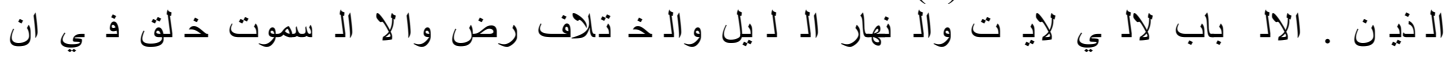

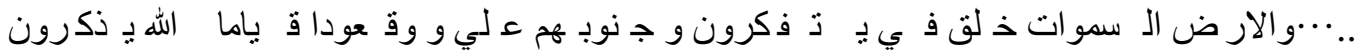

Terjemahannya:

Sesungguhnya dalam penciptaan langit dan bumi dan silih bergantinya malam dan siang terdapat tanda-tanda bagi ulil albab. Yaitu mereka yang berzikir (mengingat) Allah sambil berdiri, atau duduk atau berbaring, dan mereka yang berpikir tentang kejadian langit dan bumi. ${ }^{4}$

Fungsi utama dari handphone adalah sebagai alat komunikasi melalui suara dan pesan singkat (SMS). Selanjutnya handphone berfungsi untuk menangkap siaran radio, televise, juga dilengkapi dengan fungsi audio, kamera, video, game, serta layanan internet. Kini handphone bahkan memiliki fungsi yang hampir sama dengan perangkat komputer. Namun pada intinya, pengertian handphone adalah sebagai sebuah alat telekomunikasi sehingga fungsi utamaya adalah untuk berkomunikasi baik melaui suara maupun pesan singkat.

Komunikasi merupakan proses penyampaian pesan dari komunikatir kepada komunikan, baik secara langsung maupun tidak langsung. Dalam hal ini, menggunakan media komunikasi sebagai perantara penyampain dan penerimaan pesan. Secara umum, tujuan komunikasi adalah supaya yang disampaikan komunikator dapat dimengerti oleh yang lainnya, dapat memahami orang lain, dan sebagainya. Dalam manfaatnya, dampak yang ditimbulkan komunikasi memiliki fungsi yang sangat berperan dalam kehidupan masyarakat. Secara umum, fungsi komunikasi adalah sebagai kendali, motivasi dan informasi. Sebagai kendali memiliki arti bahwa komunikasi bertindak untuk mengendalikan perilaku orang lain, sebagai motivasi memberikan perkembangan dalam memotivasi dan memberikan penjelasan dalam hal-hal di kehidupan, dan untuk memberikan informasi yang diperlukan dari setiap individu serta kelompok dalam pengambilan keputusan.

Telepon seluler adalah salah satu media penyampai dan penerima pesan yang sangat efektif. Tidak ada lagi batasan ruang dan waktu dalam menyampaikan pesan dengan menggunakan telepon seluler. di bagian dunia manapun, aslakan tersedia jaringan telepon, orang- orang dapat berkomunikasi. Istilah terbaru dari telepon seluler yang hampir digunakan oleh setiap manusia adalah Smartphone (telepon pintar).

Beberapa Manfaat Smartphone Bagi Kehidupan Manusia : ${ }^{5}$

1. Komunikasi Antar Manusia

Smartphone adalah suatu bentuk pengembangan terbaru dari teknologi telepon nirkabel. Dengan smartphone seseorang dapat melakukan komunikasi seperti handphone biasa pada umumnya, yaitu seperti untuk telepon suara, mengirim pesan

\footnotetext{
${ }^{4}$ Departemen Agama RI, Al-Qur'an Dan Terjemahannya, h. 143.

${ }^{5}$ Kasemin, Kasiyanto. Agresi Perkembangan Teknologi Informasi (Jakarta: Kencana , 2015)h. 37.
} 
sms, pesan mms, dan layanan data. Akan tetapi smartphone dilengkapi dengan prosesor, memori, dan perlengkapan lainnya yang lebih canggih mirip seperti teknologi yang ada pada komputer.

2. Mencari Informasi / Ilmu

Berselancar di dunia internet jauh lebih nyaman jika menggunakan smartphone daripada handphone biasa yang belum dilengkapi dengan teknologi yang canggih. Berselancar di dunia maya akan terasa lebih cepat dengan smartphone yang menggunakan koneksi internet tanpa kabel generasi terbaru seperti 3G, 3,5G, 4G, 4,5G, 5G, dan seterusnya. Ditambah lagi dengan web browser terbaru yang dapat menerjemahkan bahasa html dan bahasa permograman web serta teknologi terbaru lainnya.

3. Hiburan

Smartphone dapat menayangkan berbagai format multimedia yang ada. Media streaming online pun juga dapat dengan mudah dijalankan di smartphone yang canggih tanpa banyak kendala. Ditambah lagi dengan adanya berbagai aplikasi hiburan gratis yang dapat diunduh secara gratis maupun berbayar menambah lengkap sarana hiburan yang ada pada smartphone.

4. Aplikasi

Pengguna smartphone dapat memasang dan menjalankan berbagai aplikasi yang tersedia di internet dan juga non internet yang sesuai dengan sistem operasi yang digunakannya. Setiap aplikasi memiliki spesifikasi minimal yang dibutuhkan agar dapat berjalan dengan lancar. Semakin canggih dan baru suatu gadget smartphone yang digunakan, maka pada umumnya semakin banyak aplikasi yang bisa dijalankan.

5. Penyimpanan Data

Kapasitas memori smartphone yang besar bisa berfungsi sebagai media penyimpanan data file. Seperti halnya USB flashdisk, USB external drive dan multimedia card. Handphone yang canggihpun dapat dipergunakan untuk meletakkan berbagai file sesuai dengan kapasitas yang ada pada smartphone. Smartpone yang diberi kartu memori tambahan akan mampu menampung data lebih besar.

6. Gaya

Ada banyak orang yang menggunakan smartphone untuk menunjang penampilan sehari-hari. Orang yang memiliki gengsi yang tinggi akan berusaha sekuat tenaga untuk menggunakan smartphone yang dipandang orang sebagai suatu hal yang keren dan canggih.

7. Penunjuk Arah

Salah satu fungsi penting dari smartphone adalah untuk mendapatkan informasi arah mata angin, arah kiblat, dan lain sebagainya. Smartphone yang memiliki fasilitas GPS dapat menunjukkan arah mata angin seperti layaknya kompas sungguhan. Selain itu dengan dipadukan layanan jejaring sosial maka dapat menjadi sesuatu yang sangat menarik dan dibutuhkan.

Dalam QS Yunus/ 10:24 dijelaskan 
"Sesungguhnya perumpamaan kehidupan duniawi itu adalah seperti (hujan) yang Kami turunkan dan langit, lalu tumbuhlah dengan suburnya karena air itu tanamtanaman bumi, di antaranya ada yang dimakan manusia dan binatang ternak. Hingga apabila bumi itu telah sempurna keindahannya dan memakai (pula) perhiasannya dan penghuni-penghuninya telah menduga bahwa mereka mampu menguasainya (melakukan segala sesuatu), tiba-tiba datanglah kepadanya azab kami di waktu malam atau siang, maka kami jadikan (tanaman-tanamannya) laksana tanamantanaman yang sudah disabit, seakan-akan belum pernah tumbuh kemarin. Demikianlah kami menjelaskan tanda-tanda kekuasaan (Kami) kepada orang-orang yang berpikir (QS Yunus [10]: 24). ${ }^{6}$

\section{Perspektif Islam tentang Penggunaan Telepon Seluler}

Sesungguhnya pesawat telepon dengan segala kemudahannya telah memegang peran yang sangat penting dan memberikan jasa yang besar berupa penghematan banyak hal, baik waktu, biaya, dan transportasi. Tidak disangkal, ponsel merupakan suatu anugerah yang besar. Sehingga dengan ponsel itu, seseorang bisa menyelesaikan banyak urusannya secara lebih cepat dan lebih mudah. Tetapi perlu diperhatikan pula adanya hal-hal yang bisa menyebabkan hilangnya nikmat syukur pada anugerah besar ini.

Dalam hal ini, Islam berpandangan bahwa diharuskan para pengguna handphone ini mengetahui bahwasannya Islam menilai dari para pengguna menggunakan handphone dan akan bernilai mudharat apabila pengguna tidak menggunakannya dengan bijak. Maka pada hal ini, para ulama telah merumuskan dan menentukan bagaimana pengguna memahami etik dan adab menggunakan handphone. Maka dari itu, berikut adalah beberapa adab untuk menggunakan handphone $:^{7}$

1. Menyingkat pembicaraan.

Percakapan melalui media telepon hendaknya dilakukan sesingkat mungkin untuk menghindari pemborosan uang/pulsa jika tidak ada keperluan mendesak dan guna tidak mengganggu lawan bicara dengan pembicaraan yang panjang. Maka disarankan bagi seseorang yang menelepon untuk menyingkat pembicaraannya ketika menanyakan suatu hal, menghindari pembicaraan yang terlalu lama berbasa-basi.

Hendaknya dia menahan diri untuk tidak terlalu sering menelepon tanpa keperluan yang benar-benar penting. Juga jangan suka mengumbar kata-kata saat menelepon. Karena ada sebagian orang yang betah berlama-lama saat menelepon hingga berjamjam.

2. Tidak menyusahkan penerima telepon.

\footnotetext{
${ }^{6}$ Departemen Agama RI, Al-Qur'an Dan Terjemahannya, h. 352.

${ }^{7}$ Bakar, Osman. Tauhid \& Sains : Perspektif Islam tentang Agama \& Sains (Jakarta: Pustaka Hidayah, 2010).h. 87.
} 
Misalnya menelepon orang dan mengujinya dengan pertanyaan: "Apakah kamu mengenalku?" Ketika dijawab "Tidak", malah mencela dan menyalahkannya karena sudah tidak mengenalnya lagi atau karena tidak menyimpan nomor ponselnya. Padahal si penerima kadang lebih tua darinya, lebih alim atau terpandang. Mungkin dia memang tidak bisa menyimpan nomornya di ponsel atau disebabkan kapasitas ponsel yang penuh dan tidak mampu menampung nomor lebih banyak.

Maka selayaknya si peneleponlah yang harus memperkenalkan diri di awal pembicaraan jika memang ingin dikenali. Hindarilah cara menelepon yang menyusahkan tersebut. Diriwayatkan dari Jabir bin Abdullah, berkata:

Aku datang kepada Nabi, lalu aku memanggil beliau. Beliau bertanya: Siapa?" Maka aku jawab: "Saya". Beliau keluar sambil berkata: "Saya... saya..." (menunjukkan beliau tidak suka dengan jawaban "saya" tersebut). (HR. Bukhari dan Muslim ). ${ }^{8}$

3. Menjaga perasaan penerima telepon dan tidak membuatnya tersinggung.

Mungkin dia sedang sakit atau sedang di tempat yang tidak layak untuk ngobrol, misalnya di masjid atau saat pemakaman. Atau sedang berbicara di forum orang banyak yang dia tidak ingin memotong pembicaraan mereka, dan sebagainya. Bila ternyata panggilan tidak dijawab atau dijawab dengan sangat singkat, maka hendaknya si penelepon memaafkan dan memaklumi keadaannya.

Tidak berburuk sangka kepada penerima telepon. Dan bagi si penerima telepon hendaknya memberi tahu keadaannya, atau menjawab dengan singkat pada saat ada kesempatan, yang bisa dipahami oleh penelepon bahwa dia sedang berada di tempat yang belum bisa bicara panjang lebar. Dengan begitu akan lebih menenangkan hati dan jauh dari prasangka buruk.

4. Mematikan ponsel atau mengaktifkan tanpa nada (mode silent, shamit, diam) saat memasuki masjid.

Tujuannya agar tidak mengganggu orang yang shalat dan mengurangi kekhusyu'an mereka. Jika terlupa mematikan ponsel atau memasang mode silent, lalu tiba-tiba ada yang menelepon, segeralah matikan atau hilangkan suaranya seketika itu juga. Karena sebagian orang membiarkan ponselnya tetap berdering, bahkan dengan nada musik yang mengganggu. Tidak dimatikan, tidak juga diredam suaranya dengan alasan takut melakukan gerakan selain gerakan shalat. Padahal perlu dia ketahui bahwa gerakannya mematikan ponsel tersebut adalah untuk kekhusyu'an shalatnya, bahkan untuk jama'ah lainnya secara umum.

Sebaliknya kita juga harus berlapang dada jika ada orang yang lupa mematikan ponselnya. Tidak serta merta menegurnya dengan keras dan memandangnya dengan sinis. Terutama jika dia orang yang mudah tersinggung, atau mudah marah. Karena mungkin saja dia tidak sengaja dan hanya lupa. Sehingga tidak seharusnya diperlakukan dengan perlakuan yang menyakitkan.

\footnotetext{
${ }^{8}$ Syuhudi Ismail, Pengantar IImu Hadis, h. 124.
} 
Cukuplah bagi kita teladan yang baik pada diri Rasulullah ketika beliau sangat berlemah lembut terhadap seorang Badui yang kencing di masjid. Beliau memerintahkan untuk menyiram bekas air kencing itu dengan setimba air. Abu Hurairah berkata: "Seorang badui berdiri lalu kencing di masjid. Seketika itu juga orang-orang yang hadir menghardiknya. Tapi Nabi berkata pada mereka: "Biarkan dia selesai. Lalu siramlah kencingnya dengan setimba air. Sesungguhnya kalian diutus untuk mempermudah, bukan untuk mempersulit." (HR. Bukhari)

5. Menghindari penggunaan nada dering lagu dan musik.

Karena di dalamnya terdapat larangan keharaman dan celaan terhadap akal orang yang menggunakan nada lagu dan musik tersebut. Karena hal ini sangat mengganggu, terlebih jika sampai dipergunakan dalam masjid atau majelis-majelis umum.

6. Tidak menggunakan ponsel pada saat berada di majelis ilmu atau pada forumforum besar secara umum.

Karena hal itu bisa mengurangi wibawa majelis dan mengganggu orang yang sedang menuntut ilmu. Menyakiti perasaan pembicara yang sedang menyampaikan pelajaran atau materi dan menimbulkan cercaan terhadap pengguna ponsel tersebut. Disarankan agar tidak menelepon atau menjawab telepon ketika sedang berada dalam suatu pertemuan yang dipimpin oleh orang yang mulia, diisi oleh pembicara tunggal, atau terdapat orang yang lebih tua dan dimuliakan. Karena menelepon atau menjawab panggilan telepon pada saat itu bisa memutuskan pembicaraan dan mengganggu konsentrasi hadirin. Serta merusak etika berbicara dan bermajelis.

Abu Tammam berkata: "Siapakah yang engkau buat murka atau kau bodohi, sedangkan ia membalasnya dengan kesabaran dan kearifan kau lihat dia memperhatikan pembicaraan dengan sungguh-sungguh dan dengan sepenuh hatinya padahal ia mungkin lebih memahaminya"

Menelepon atau menjawab telepon pada kondisi di atas dimaklumi apabila memang darurat atau ada kebutuhan mendesak yang dikhawatirkan hilangnya kesempatan setelah itu. Tentu dengan tetap menjaga agar tidak memperpanjang percakapan. Dimaafkan juga bagi pemimpin majelis atau orang tua untuk menelepon atau menjawab panggilan telepon. Begitu pula pada pertemuan biasa dengan keluarga atau teman-teman, maka tidak mengapa menerima atau menelepon. Sangat bijaksana jika seseorang yang akan menelepon untuk minta izin terlebih dulu dan keluar dari forum.

7. Jangan merekam pembicaraan atau mengaktifkan suara luar di tengah orang banyak tanpa sepengetahuan lawan bicara.

Kadang hal itu terjadi ketika seseorang menelepon salah seorang temannya atau sebaliknya dia yang ditelepon, diam-diam dia merekam pembicaraan tersebut, atau memperdengarkan suaranya melalui speaker luar, padahal di sekitarnya ada orang lain yang mendengar pembicaraan tersebut. Perbuatan ini tentu tidak pantas dilakukan oleh orang yang berakal, terutama jika pembicaraan itu adalah pembicaraan yang 
bersifat khusus atau rahasia. Hal ini bisa menjadi bagian dari jenis khianat atau bentuk adu domba. Lebih tidak pantas lagi jika lawan bicara adalah orang yang berilmu, lalu dia merekam semua yang dibicarakannya tanpa sepengetahuannya, kemudian dia sebarkan melalui media internet atau dia tulis ulang dengan melakukan penambahan dan pengurangan.

8. Menjaga sopan santun dalam menulis pesan singkat.

Kemampuan kirim-terima pesan singkat (SMS) memang merupakan salah satu fitur yang digemari pada ponsel. Namun pengguna ponsel yang berakal haruslah memperhatikan tatakrama dan aturan dalam menggunakan SMS. Hendaknya dia menulis SMS dengan bahasa yang indah, mengandung pelajaran, kabar gembira, pelipur duka atau menyenangkan. Bagus juga berisi pesan-pesan yang mengandung hikmah, dzikir, nasehat, kata mutiara atau semacamnya.

9. Meneliti kebenaran suatu pesan.

Jika suatu pesan singkat (SMS) mengandung suatu informasi, maka konfirmasikan dulu kebenarannya sebelum mengirimnya. Jika berisi suatu berita, pastikan dulu bahwa berita tersebut benar adanya. Karena mungkin berita itu akan diteruskan ke orang lain. Pengirim mestinya paham bahwa pesannya bisa saja berpindah tangan dan tersebar kemana-mana. Bila pesan baik yang dia kirimkan, dia akan mendapatkan manfaatnya. Namun jika pesan buruk yang dia sebarkan, maka bersiaplah menuai akibatnya. Maka perhatikanlah pesan yang akan dia kirimkan itu, akan mendatangkan kebaikan ataukah justru berdampak buruk.

Hal-hal yang juga perlu diwaspadai adalah adanya kebiasaan menulis nasehat melalui pesan singkat untuk melakukan amalan-amalan tertentu tanpa memperhatikan hukumnya syar'i atau tidaknya.Misalnya nasehat untuk melakukan puasa akhir tahun karena bertepatan dengan hari Senin, mengkhususkan do'a tertentu dengan kebaikan atau keburukan seorang tertentu dan pada waktu tertentu, atau mengirim pesan pada seseorang dan mengharuskannya meneruskan pesan tersebut ke sepuluh orang lainya atau sejumlah orang tertentu. Hal seperti ini tidak layak dilakukan, karena hal itu bisa menjerumuskan seseorang ke dalam hal-hal yang diada-adakan dan bid'ah. Adapun saling menasehati agar mendoakan kaum muslimin, melaknat musuh-musuh agama, memanfaatkan waktu dan tempat dengan kebaikan dan semisalnya maka hal itu boleh. Tanpa mengkhususkan dengan do'a tertentu.

10. Hindari pesan-pesan SMS yang tidak baik.

Misalnya mengandung kata-kata jorok, celaan, gambar tak senonoh atau foto-foto porno, atau ucapan yang memiliki dua makna baik dan buruk. Pada saat awal membaca pesan tersebut yang ditangkap adalah makna buruk, namun setelah diamati dengan seksama diketahui bahwa maknanya adalah baik. Atau kalimat yang diputus dengan spasi cukup panjang sehingga lanjutan kalimat tersebut baru terbaca setelah menekan tombol ponsel. Semua itu menunjukkan perilaku dan etika yang buruk. 
Al-Mawardi berkata: "Dan yang termasuk perkataan buruk, yang wajib dijauhi dan mesti dihindari adalah kata-kata yang bertolak belakang. Mulanya dipahami sebagai kata-kata buruk. Lalu setelah diteliti dan dipahami dengan benar ternyata bermakna baik". (Adabud Dunya Wad Dien: 284).

Dilarang pula bercanda dengan berlebihan. Atau menggunakan kalimatkalimat cinta, terutama terhadap wanita. Karena wanita sangat suka dipuji dan mudah tergoda rayuan. Ucapan lainnya yang juga dilarang adalah yang mengandung celaan, fitnah dan lainnya. Semua hal tersebut dilarang karena menyelisihi syar'i, merusak adab, dan bisa menghilangkan syukur terhadap nikmat pada perangkat ponsel ini.

Pada hal ini, ketika kita menggunakan handphone untuk kebutuhan, maka harus sepatutnya kita mengamalkan adab menggunakannya. Ketika kita menggunakannya dengan bijak, maka Islam pun memandang handphone ini sangat bermanfaat karena memudahkan kesulitan ketika berinteraksi dengan lingkungan dan masyarakat sekitar. Akan tetapi apabila handphone ini digunakan dengan tidak baik, maka Islam pun akan berpandangan bahwa handphone memiliki banyak mudharat dan bisa menjerumuskan pengguna kepada maksiat yang tentu saja tidak diinginkan oleh Islam sendiri. Makanya mari menggunakan handphone sebaik mungkin.

\section{Kesimpulan}

Telepon seluler merupakan alat komunikasi yang diciptakan manusia untuk memudahkan proses komunikasi. Seiring dengan perkembangan teknologi, telepon selulerpun berkembang dari sekedar digunakan untuk menelepon dan mengirim pesan. Jauh sebelum telepon seluler ini dibuat oleh manusia, Al-Quran sudah menjelaskan akan hadirnya teknologi tersebut. Seperti yang termaktub dalam QS. Yunus/11 dan 24, yang menjelaskan tentang bagaimana memanfaatkan segala sesuatu yang ada dibumi ciptaan Allah. Telepon seluler merupakan alat yang diciptakan oleh manusia untuk dipergunakan dalam memudahkan kebutuhan hidup. Segala sesuatu akan berguna jika digunakan sebagaimana mestinya dan akan merusak jika tidak digunakan sesuai tujuan pembuatannya. Pada hal ini, ketika kita menggunakan handphone untuk kebutuhan, maka harus sepatutnya kita mengamalkan adab menggunakannya.

\section{DAFTAR PUSTAKA}

Bakar, Osman. Tauhid \& Sains : Perspektif Islam tentang Agama \& Sains ; Pustaka Hidayah; Jakarta, 2010.

Cangara, Hafied. Pengantar Ilmu Komunikasi; Jakarta: Rajawali Pers, 2016.

Hamzah, B,Uno, dan Lamtaenggo, Nina. Teknologi komunikasi dan informasi pembelajaran ; PT. Bumi Aksara : Jakarta, 2011.

Kasemin, Kasiyanto. Agresi Perkembangan Teknologi Informasi ; Kencana ; Jakarta, 2015.

Noegroho, Agoeng. Teknologi dari A-Z ; PT Raja Grafindo Persada : Jakarta, 2017. 
Saydam, Gouzali. Teknologi Telekomunikasi ( Perkembangan dan Aplikasi) ; Alfabeta, Jakarta, 2005.

Referensi Tambahan

https://alihasanasyariblog.wordpress.com/2016/05/16/penggunaan-handphone-dalampandangan-islam/

https://ourcomputerappblog.wordpress.com/2016/07/15/ayat-al-quran-tentangteknologi-dan-informasi/ 